\title{
Mining and Environmental Rights in Zimbabwe. A Case of Zvishavane District
}

\author{
Elvis Munyoka \\ School of Social and Political Sciences, University of Glasgow, G12 8QQ, Glasgow, Scotland, United Kingdom
}

\begin{abstract}
This paper examines the impact of artisanal small-scale mining on the environmental rights of communities in Zvishavane, Zimbabwe. All over the world, mining has been significant in enhancing the livelihoods of the people by reducing poverty and ensuring food security. Despite its major contribution to economic growth and development, mining is responsible for environmental degradation. The environmental rights of many indigenous communities in Zimbabwe are violated by small-scale mining operations. Zvishavane is one of the marginalized communities in Zimbabwe where all types of mining activities are taking place as the district is located along the Great Dyke mineral belt. The dominant mining entities in the district are artisanal small-scale miners exploiting gold and chrome. Given the low capitalization that characterizes artisanal small-scale miners, the degree to which these entities comply with the country's legislation on environmental protection becomes very doubtful. The study was conducted through interviews and focus group discussions with key informants in the Mapanzure community in Zvishavane. The findings of this study highlight that artisanal small-scale chrome and gold miners are largely responsible for the contamination of water sources, land degradation, excessive air pollution and deforestation, which exposes mining communities in Zvishavane to health hazards such as cholera, bilharzia, asthma and cirrhosis. Findings of this study provide valuable insights for policymakers and practitioners on sustainable mining in marginalized communities.
\end{abstract}

Keywords: Mining, Environmental rights, Artisanal small-scale miners and Zvishavane District

DOI: $10.7176 / \mathrm{DCS} / 10-8-06$

Publication date:August $31^{\text {st }} 2020$

\section{Introduction}

Mining significantly contributes to the development of Zimbabwe and continues to bring much-needed income (Kaseke et al., 2015; Murombo, 2013). Mining has become a poverty alleviation scheme in the country owing to endemic poverty and skyrocketing inflation (Mapuranga, 2020). The mining sector essentially yields the Gross Domestic Product, contributing to infrastructural development, foreign exchange and revenue in Zimbabwe (Franks, 2017). Artisanal small-scale mining indicates an economic activity which combines informal, medium and small, unregistered and registered miners practicing primitive techniques of mining to exploit mineral deposits (Mawowa, 2013). Environmental rights relate to fundamental rights to stay in a healthy environment, that involves enjoying clean land, water, natural resources and air vital for subsistence (Brisman, 2014).

Artisanal small-scale mining is commonly practiced in emerging economies of Latin America and Africa (Arthur et al, 2016; Hilson, 2016; Ross, 2001). In 2019, artisanal small-scale mining contributed $63 \%$ of the total gold delivered to the Fidelity Printers and Refiners in Zimbabwe (Zimbabwe Environmental Law Association (ZELA), 2020). It is anticipated that the country's development agenda during this new dispensation will continue to be subsidized by the earnings from the mining sector (Mapuranga, 2020). The mining sector became the fastest growing sector since 2009 owing to the failure of the antagonistic macro and microeconomic policies like the Indigenization Economic and Empowerment Act which saw the closure of many companies hence trapping the country into acute shortages of basic commodities (Chipika \& Malaba, 2011). Many mining activities happen in remote areas endowed with natural resources such as Zvishavane (Mtisi, 2010). Many mining activities have occurred in Zvishavane, ranging from small-scale to large-scale mining companies (ZELA, 2011). Artisanal smallscale miners both legal and illegal are dominant in exploiting mineral deposits (Kaseke et al., 2015). However, illegal small-scale mining tends to overshadow legal mining. Mapuranga (2020) argues that the number of formal artisanal miners is above 35000 in Zimbabwe whilst over one million mines illegally. Yet the government of Zimbabwe is delaying to formalise artisanal miners which exacerbate illegal mining (Mapuranga, 2020).

The prevalence of artisanal small-scale miners started in 2009 when the government of Zimbabwe granted several small-scale miners the mining rights to exploit gold (Mtisi, 2010). The granting of mining claims promoted the proliferation of artisanal mining which aggravated environmental degradation (ZELA, 2011). While artisanal mining has significantly enhanced the livelihoods of communities in Zvishavane it has also destroyed the natural landscape, violated human rights, contaminated soils, polluted surfaces, groundwater resources and displaced people. This research was conducted to examine the impacts of artisanal small-scale mining on the environmental rights of people in the Mapanzure community. 


\section{Literature Review}

Over the last decade, the political and economic disasters in Zimbabwe have constrained the livelihoods of the people both in urban and rural areas of the country (Rutherford, 2014; Scoones et al., 2012). The increasing economic crisis faced by the country left limited employment opportunities in the formal sector (Rutherford, 2017; Mabhena, 2012). Many individuals have joined small-scale mining as a major livelihood pathway, especially in communities with abundant mineral resources such as Zvishavane, Shurugwi, Gwanda and Mberengwa (Mapuranga, 2020). While the crucial role of mining to the economic growth of the country is well recorded, little attention has been given to the challenges posed by mining activities to the local communities and the environment.

Indigenous communities are marginalised, yet they deserve the same dignity and respect other members enjoy in the society. According to the United Nations Declaration on the Human Environment (1972), everyone has the basic right to equality, freedom and suitable conditions of life, in a quality environment which promotes wellbeing and dignity. This includes the protection and recognition of the rights of indigenous communities often disadvantaged and unable to benefit from resources found in their communities (Spiegel, 2015). It is imperative to understand the perceptions of communities on the challenges they experience due to extreme mining operations.

Many developing economies are supported by the mining sector (Hirons, 2014; World Bank, 2013; Ross, 2001). In Ghana, DRC, South Africa and Botswana mining play an important part in sustaining the livelihoods of the people (Hawkins, 2009; Hammar, 2010). For example, South Africa has huge gold deposits and its economy is reliant on mining as the biggest earner of foreign currency (Mabhena, 2012). In Ghana, mining accounted for 42 per cent of the country's foreign earner (Thomas, 2000). According to Hayes (2008), approximately 26.4 per cent of Zimbabwe's population relied on small-scale mining in the economic crunch of 2008, which made Zimbabwe to land number four on the list of countries which depend on artisanal small-scale mining in Africa. Recently, artisanal small-scale entities have produced 17478.74 kilograms of gold delivered to the Fidelity Printers and Refiners in 2019 (ZELA, 2020). They contributed more than half of the total produce which was 27650.26 kilograms highlighting the significance of mining in the new dispensation in Zimbabwe.

In developed countries, mining contributes less to environmental degradation as compared to countries in the developing world where primitive techniques of mining are prevalent. Rutherford (2017) argues that nearly in all the African countries mining is primitive and undeveloped methods are often applied to extract ore from the ground which degrades the environment. For instance, in Ghana mining accounts for 95 per cent of the total export earnings, while less than one-third of the income is channelled towards corporate social responsibility initiatives (Spiegel, 2015; Thomas, 2000). This is a unique situation in most developed countries such as Canada where more earnings are directed towards corporate social responsibility. For instance, Ontario, a huge mining company invested $\$ 10.6$ billion for corporate social responsibility in 2016 . This is not the case in developing countries of Latin America, Asia and Africa. The revenue obtained from mining is diverted to political activities such as rallies and election campaigns without investing in environmental protection (Mtisi, 2010). This causes environmental and socioeconomic discrepancies. Anderson (2017) maintains that in several African states, mining is responsible for environmental degradation in comparison to other parts of the world. Specifically, in sub-Saharan Africa mining effects have exceeded the global yearly average per cent of environmental change which is 0.8 per cent (Ndlovu et al., 2019).

Many communities in Zimbabwe have ventured into gold mining as a source of income to cushion themselves from the economic crisis (International Institute for Environment and Development, 2013). Ndlovu et al (2019) notes that the lack of financial capital to finance mining has incapacitated small-scale mining in Zimbabwe. Opencast mining is the commonly practised method of small-scale mining because of the lack of advanced technology and capital to practice sustainable methods of mining (Mathe et al., 2016). Most artisanal small-scale mining entities in Zvishavane are poor and practising opencast mining. Mtisi (2010) remarks that small-scale miners in Zvishavane District are practising open shaft mining as this type of mining does not involve sophisticated heavy machinery expensive to purchase.

Severe poverty and food scarcity in remote communities have triggered people to practice mining in order to secure their livelihood needs (Ndlovu et al., 2019). Due to desperation, the mining of gold in communities has become dangerous. Violent incidents have since increased in communities since the dawn of the food crisis orchestrated by the so-called Machete gangs 'gold thugs' targeting mining communities (Mapuranga, 2020). Mining has sustained the lives of local communities suffering from abject poverty and food scarcity, but on the other hand, it has caused massive environmental degradation which will be examined in detail below.

Over the past decades, the discussions about environmental protection and environmental rights have gained momentum. Environmental rights are difficult to define and classify as they are closely related to other types of rights such as civil and political rights and socioeconomic rights. Environmental rights can be grouped into three kinds notably substantive, procedural and solidarity. Substantive environmental rights are defined as active rights located within the broader framework of international human rights law and that may be used where environmental problems cause serious human rights concerns. Substantive rights consist of the right to health, the right to life, the right to privacy and the right to an adequate standard of living (Hilson, 2016). 
Moreover, Thomas (2000) argues that procedural rights are a division of environmental rights that promotes participation, transparency and accountability which forms the foundation of environmental good governance. There are four categories of procedural rights which are: public participation, access to information, access to the justice and freedom of association (Hilson, 2016). Finally, solidarity rights centre upon the environment. Dissimilar to other rights protected by the state in isolation, solidarity rights call for global participation for successful implementation. They represent a broader community, hence universal cooperation is required towards a habitable world (Thomas, 2000). Therefore, solidarity environmental rights revolve around the principles of nondiscrimination and self-determination.

\section{Problem Statement}

The decline of the most productive sectors of the economy and increasing poverty in rural communities of Zimbabwe have left people with few opportunities for securing their livelihoods. In Zvishavane communities endowed with mineral resources, many people have turned to artisanal small-scale mining to survive. However, limited financial resources prompted the use of rudimentary technology which has resulted in excessive environmental destruction. Environmental degradation compromises the basic privileges of communities to stay in a safe and clean environment. Artisanal small-scale miners need to practice sustainable mining techniques to safeguard the environment and the rights of the people in marginalised communities. This study aims at investigating the impact of artisanal small-scale mining activities on the environmental rights of the people in the Mapanzure community of Zvishavane District. An understanding of the environmental challenges caused by artisanal small-scale miners on the local communities is key in informing policy formulation to ensure sustainable mining and ecological protection.

\section{Research Questions}

The overall aim of the paper is to examine the extent to which artisanal small-scale mining has impacted on the environmental rights of the people in Mapanzure community in Zvishavane District. The research is guided by the following research questions:

1. What is the key legislation governing mining operations in Zimbabwe?

2. What are the impacts of artisanal small-scale mining on the environmental rights of people in the Mapanzure community?

3. What attempts have been made by small scale mining companies to safeguard the environmental rights of the people in the Mapanzure community in line with legal provisions?

\section{Research Methodology}

A qualitative research approach was employed to gather data for this study. Data were collected through focus group discussions, face to face interviews and secondary sources. A total of 10 face to face interviews were conducted. Respondents were purposefully sampled and asked unstructured questions to understand their experiences and perceptions about environmental challenges caused by artisanal small-scale mining in the Mapanzure community. Interviews were held with the District Administrator, chief Mapanzure, kraal heads, artisanal small-scale miners and villagers.

Four focus group discussions were conducted with community members in the Mapanzure community. Each focus group discussion consisted of six individuals and participation was voluntary. Two focus group discussions were conducted with men only and two others with women alone. Men and women were separated from each other to give women the confidence to participate and avoid possible biases associated with mixed groups. Focus group discussions were instrumental in allowing the researcher to have a comprehensive understanding of the effect of small-scale mining operations on the environmental rights of the people in the Mapanzure community.

Secondary sources of data were also used alongside face to face interviews and focus group discussions. The literature analysed includes published documents on artisanal small-scale mining by Mining Zimbabwe and Zimbabwe Environmental Law Association. Critical areas concerning the impact of mining have been covered by these organisations which include the effect of small-scale mining on the environment. All the sources were analysed to answer the main research objective of this study which is to examine the impact of artisanal smallscale mining on the environmental rights of mining communities in Mapanzure.

Data were analysed thematically. Thematic analysis is "a form of pattern recognition within the data, with emerging themes becoming the categories for analysis, involving a focused re-evaluation and review of the data" (Fereday \& Muir-Cochrane, 2006:83). Ramara et al (2010) defines data analysis as the process of creating order, structure and meaning to the data gathered for its explanatory and meaningful quality. Thematic analysis was carried out in line with the six steps outlined by Braun and Clarke (2006) which are: familiarising with the data collected, assigning codes to the data, theme searching, reviewing of the themes, defining and naming themes and finally the writing of a report about the observations. Findings were presented chronologically to answer the research question guiding the study. 
To ensure the trustworthiness of the findings, the researcher selected participants who were experts in the area of mining, people with lived experiences of the impacts of small-scale mining activities in Mapanzure area. The aim of the research interviews was explicitly explained to the interviewees in the local language so that everyone could understand. A local language (Shona) was used during the interviewing process so that participates would freely participate in the discussions. Participants were allowed to seek clarification during the interviewing process should there need to ensure that accurate answers are provided. The credibility of the results was improved by the practice of critical reflexibility whereby the researcher avoided bias by distinguishing participants' views and the researcher's interpretations (Lincoln \& Guba, 1985). The researcher also noted down detailed notes which made the audit of the study results viable. To ensure dependability, the researcher explained the data collection and analysis process clearly so that it can be traceable by readers. The findings were compared with information found by other researchers in the literature analysed to ascertain relevance. Therefore, the results of this study are confirmable because all the steps of ensuring trustworthiness were exhausted.

\section{The legal Context of Mining and Environmental Rights in Zimbabwe}

Many pieces of legislation exist in Zimbabwe on the governance of the mining industry and environmental protection to ensure sustainable mining practices (Mawowa, 2013). The legislative frameworks on environmental protection predominantly consist of the Mines and Minerals Act, the Environmental Management Act, the Constitution of Zimbabwe, and the Zimbabwe Investment Authority Act. The Mines and Minerals Act of Zimbabwe although an ancient piece of legislation remains one of the most important legal frameworks in the management of mining in the country (ZELA, 2011). The Act outlined many provisions concerning how mining entities should operate. Some of the provisions include the issuance of mining licences, Exclusive Property Orders and Special Grants for exploration in reserved areas (Chamber of Mines, 2012).

The mining licences stipulate the requirements that should be met by mining investors both local and foreign applicants before beginning operations on the ground. As part of the requirements encapsulated in the Act, proposals must be submitted with plans towards the prevention of pollution, disposal and treatment of wastes, the reclamation and rehabilitation of land degradation, the protection of rivers and other sources of water as well as the monitoring of the overall effects of mining on the environment (Kaseke et al., 2015). Deforestation is also prohibited by the Mining and Minerals Act. However, the application of this Act is questionable to artisanal smallscale miners that continue to mine illegally and cause serious ecological destruction. Some of the major issues surrounding the lack of implementation include rife corruption by enforcing agents who accept bribes because of poverty (Mtisi, 2010).

The Environmental Management Act is another imperative piece of legislation regarding environmental management in Zimbabwe (Spiegel, 2015). The Environmental Management Authority (EMA) was established to regulate environmental protection previously governed by fragmented pieces of legislation adopted from the colonial regime (ZELA \& SARW, 2011). The Act warranties every person the right to stay in a safe and clean environment that does not harm health. In terms of the provisions of the Act, every person must participate in the application of policy measures that avoid environmental degradation and ensure the sustainable management and utilisation of ecological resources to promote socio-economic development (section 4(1) (c) of EMA).

The Act compels investors to prepare Environmental Impact Assessments (EIA) reports which demonstrate the potential environmental, economic and social impacts of their projects on the environment. EMA requires an EIA certificate before any operations start on the ground. The Polluter Pays Principles (PPPs) is also established by EMA which stipulates the fines that should be paid by entities polluting the environment such as mining corporations or individuals. The penalty ranges from level 3 up to 14 and level 3 costs $\$ 20$ whilst level 14 costs $\$ 5000$ (figures correct as of 2018). Nevertheless, many small-scale gold miners are operating in Zvishavane without meeting EMA's requirements (Mabhena, 2012). Their activities are unregulated which result in increased environmental degradation.

The new Constitution of Zimbabwe reinforces all existing laws on the management of the mining industry by providing environmental, socioeconomic, and cultural rights that can be demanded by everyone affected indirectly or directly by mining operations (Makaza, 2015). Essentially, the Constitution protects the right of every individual to an environment that is clean and harmless to health (section 73 of the Constitution). Moreover, the state, through the Constitution is empowered to safeguard that all international conventions, agreements and treaties to which Zimbabwe is a signatory are enforced to protect the environmental rights of citizens. The declaration of the rights enshrined in the Constitution is all-inclusive in that the rights are clearly stated in such a way that they are easily recognised. Hence, the operations of all mining corporations are bound by the Constitution which safeguards the rights of the people against malicious actions by mining entities whether small-scale, large, legal or illegal.

Finally, the Zimbabwe Investment Authority statutory body propagated through the Zimbabwe Investment Authority Act is fundamental in harmonising investments within the country (Kaseke et al., 2015). The Act obliges every individual who wants to invest in the country to make an investment application that will consider diverse key aspects concerning techniques and technologies that will be utilised and prospective effects the intended 
investment will pose to the environment, as well as the measures that will be instituted to mitigate the effects. The Act also compels investors to consider the welfare of communities in which resources are extracted from rather than only concentrating on amassing revenue (Muremba, 2011). Indeed the Act is a brilliant piece of legislation about the monitoring of business operations. However, countless cases of environmental violations have been observed in Zvishavane communities. This is a clear indication that regardless of the existence of the law on paper, in praxis the law is ineffective as mining operations in Zvishavane seldomly comply and continue to impact the environment and livelihoods of communities. Serious measures must be taken to ensure sustainable mining in remote areas of Zimbabwe if agenda 2030 is to be realised.

\section{Results and Discussion}

7.1 The scope and dynamics of environmental rights and artisanal small-scale mining in Zvishavane

7.1.1 Land degradation

Land degradation is an irrefutable environmental impact related to the different phases of mining operations in Zvishavane (ZELA, 2011). Many small-scale miners and illegal artisanal gold and chrome miners operating in the district have been notorious for utilising rudimentary methods of mining (Mathe et al., 2016). Land degradation in Mapanzure is mainly a result of open cast mining which destroyed the landscape and left many open pits. For instance, the villagers in Mapanzure expressed their anger towards the way artisanal small-scale miners have depleted the environment by digging a lot of deep open pits in the area, which is reported to be approximately 30 metres deep. Respondent A said,

"You see those deep pits left by the miners, they make us sad, but we have nothing to do to prevent them. We are only afraid of our children and our livestock".

Abandoned open pits have caused great challenges to people. Villagers from Mapanzure community elicited that open pits are dangerous areas that pose a great health risk and loss of life to the people and livestock due to falls in inadequately protected mines. The small-scale gold and chrome miners have been at the forefront of disrupting the landscape because their way of mining forms large open cuts and open pits (Arthur et al., 2016). For example, villagers in Mapanzure claimed that one must be extra careful when gathering firewood because several open pits were left unrehabilitated after mining operations had ceased. Respondent B posited that,

"Because of these holes, we are afraid to let the children go alone to gather firewood in the forest because many are injured by falling into these holes".

The researcher observed that different mining activities are taking place in Mapanzure, including both large scale and small-scale artisanal miners. Mining operations are radically altering the natural environment by stripping away the ground for excavation as open cast mining requires large tracks of land. Through land degradation, agricultural production has declined remarkably exposing the district to poverty. Respondent $\mathrm{C}$ stated,

"We have always had a problem with rain, we cannot harvest much, and the cultivable lands are decreasing due to mining activities, which means that the famine is worsened".

Naturally, the region receives low rainfall as a result land degradation is aiding the crisis of food insecurity in the district (Ndlovu et al., 2019). Through focus group discussions held, some community members blamed big companies for degrading the environment. They overlooked the part played by artisanal small-scale mining in destroying the environment citing that mining is their livelihood pathway. It is this kind of justification that had propelled the impact of artisanal mining on the environment because of the absence of checks and balances on the part of artisanal small-scale miners.

\subsubsection{Deforestation}

Large tracks of land are cleared away during the preparation of mining activities by small-scale miners in Mapanzure. Deforestation is widespread in the mining communities of Zvishavane because mining operations are stripping larger acreages of forested land to extract minerals from the ground (Kaseke et al., 2015). Community members interviewed in Mapanzure subscribed that large pieces of land are deforested by small-scale miners who tend to be dominant in the area because they utilise archaic methods of mining such as open-cast mining. Respondent D said:

"my son as you just see there are many open holes everywhere dug by gold miners. Our cattle have nowhere to feed".

Rudimentary techniques of mining practised by artisanal small-scale miners are unsuitable for carrying out underground mining (Ndlovu et al., 2019); implying as soon as they exhaust the top deposits, they should migrate to lucrative land eventually destroying the environment. Often women involved in small-scale mining are affected most as they lack resources to purchase compressors, generators and drillers needed for underground mining. Respondent E stated,

"As women, we have a shortage of resources needed for mining, which is why many of us are unable to do the work because it requires so much money”.

Chief Mapanzure indicated that small-scale miners are less concerned about the immediate effects of their mining activities like digging, deforestation because those are the very first activities they engage in when panning. 
Respondent F said,

"We have already sat down as leaders to discuss the issue of these miners but with the difficulty of life here people continue to dig at night".

The removal of vegetation cover and topsoil remove nutrients and alter the biological systems of the soil making it vulnerable to forces of erosion (Grant, 2006). Climatic conditions of the district are changing progressively, and the problem can be largely attributed to deforestation and air pollution that is causing greenhouse effects in the atmosphere. The consequences of mining are impacting the lives of the people due to the decline of the major livelihood sources of food such as agriculture and animal husbandry (ZELA, 2020).

\subsubsection{Water Contamination}

Water contamination is a critical environmental impact of small-scale gold mining in Mapanzure. Underground water sources are contaminated due to the irresponsible activities of alluvial gold miners, explicitly through the leaching of explosives such as cyanide and mercury into the ground (ZELA, 2011; Telmer \& Veiga, 2009). Artisanal small-scale gold miners are operating in the main watercourses such as along the Ngezi River one of the key sources of water in the district. Respondent G stated that,

"EMA has previously banned people from mining in the lower rivers but this incident is only going to continue because it is the only one left for people to survive because minerals are abundant in the area".

This is against the environmental protection regulations which stipulate that any mining activity should be undertaken 30 metres away from the water source. The contamination of big rivers such as Ngezi has intensified the dilemma of water scarcity in the communities of Zvishavane. Communities must get water from boreholes as water from open sources such as rivers is no longer safe to drink due to pollution, exposing people to water-borne diseases.

Moreover, communities pointed out that household wells and boreholes are fast drying up because of underground seepage as water drains out quickly from the open pits left by small-scale miners. Respondent $\mathrm{H}$ said:

"Now we have no real drinking water because of these pits, our water wells are drying up so quickly and the livestock that we look for are not able to find drinking water right now. We are worried here about the water crisis".

Small-scale miners are also notorious for open defecation as they are reluctant to build temporary toilets at their mining sites. Open defecation compounds water contamination in the district as human excreta is drained directly into the rivers and wells. Small-scale gold and chrome miners in Zvishavane district are extremely irresponsible, they are dumping both liquid and solid wastes produced by their mining operations back into the key water bodies such as Ngezi river (ZELA, 2011).

The pollution of water sources by explosives have affected aquatic species in the area. The District Administrator pointed out that fishing and other traditional livelihood activities which are dependent on the water have been greatly affected due to water pollution leading to poverty and over-reliance on food handouts (Makaza, 2015). Community members are worried about their welfare as they are lacking access to clean and safe water as the major sources of clean water are contaminated by the miners. The district has been exposed to high risks of waterborne diseases such as cholera and bilharzia.

\subsubsection{Air pollution}

Opencast mining is the most practised type of mining in Zvishavane district (Mtisi, 2010). Opencast mining has resulted in excessive air pollution due to the clearing of surface materials in preparing the land for mining operations. Particulate matter and visible dust are the widespread effects of mining in the area (Mtisi, 2010). Air pollution is not solely caused by the blasting and processing of ore but it is coupled with the increase in excavation, cleaning of mining sites, deforestation and the movement of heavy vehicles transporting minerals deposits, causing a lot of dust to pollute the air and covering the vegetation around the mining sites. Respondent I said:

"As you can see, we are not at peace here with dust coming out when miners are digging holes and cutting down trees around their mining sites. Sometimes the whole village is covered with dust".

Dust pollution was reported to be a critical problem of mining in Mapanzure due to miners who are not employing best technologies and techniques to mitigate the levels of carbon emission into the atmosphere (ZELA, 2011).

Mabhena (2012) argues that small-scale miners cause environmental degradation because they do not practice sustainable mining to prevent negative ecological consequences. The villagers in Mapanzure were extremely worried about their health, expressing that if air pollution increases their health will continue to be threatened due to chronic diseases such as asthma and silicosis. Respondent $\mathrm{J}$,

"We are worried about influenza here because of this dust, we do not have the money to go to doctors. It hurts us a lot in this area".

The researcher observed that air pollution, especially from dust and particulate matter, has disturbed the growth of vegetation hence biodiversity loss which affects agricultural activities of the communities further shrinking their livelihood sources in an already arid region. 


\subsection{Complaint and Compensation Mechanisms}

The compensation of environmental rights violated by mining activities is imperative in terms of environmental rights law (Anderson, 2017). The United Nations Guiding Principles on Business depict that any state must ensure that environmental rights affected by business operations, in this case, mining activities, must be compensated. Highlighting that communities impacted by mining operations must be remunerated accordingly with the harm caused to them by mining entities. Focusing on artisanal small-scale mining in Mapanzure, many environmental rights have been violated as envisaged in the discussion above. Mining activities are violating the rights of the people to a safe and clean environment through tremendous land degradation, water contamination and air pollution.

However, community members illustrated that they are not compensated by small-scale miners because they do not have complaint mechanism platforms in place that can allow community members to seek redress to damages incurred. Respondent K said:

"My cow fell into a hole left by chrome miners and died, I reported the incident, but I am tired of asking for the money to pay my cow because nothing was given to me till today by the Chinese miners".

Small-scale miners have been ignoring the law by destroying the environment and the welfare of the people, yet no efforts have been put in place to redress the damages. Additionally, many small-scale miners have infringed community environmental rights by abandoning large open pits which have led to the death of both humans and livestock. For instance, small-scale chrome miners have been responsible for causing injuries, but they have not been able to compensate injured people because of the absence of grievance redress mechanisms.

Describing the lack of remuneration, community members in Mapanzure narrated the emotional story of the death of Tariro, a 13-year-old girl who perished in the open pits left by chrome miners. The family of Tariro was not compensated because of the absence of effective grievance mechanisms that holds duty bears accountable. Also, livestock's have been exposed to dangers of falling into the open pits, respondents alleged that they approached EMA for help to recover the losses, but no compensation was received because small-scale miners are reluctant to compensate, thereby exposing community members to dangers of permanent injuries, loss of life as well as the loss of livelihood diversity.

Furthermore, the challenges of compensation encountered by communities are worsened by the ineffectiveness of government agencies such as the Environmental Management Agent and the Ministry of Mines and Mining. Respondent L stated that:

"There are only laws that protect our rights, but we have never seen their effect in this area. We just watch these holes drilled by different companies, coming and going".

The implementation of environmental protection regulations is weak (Mtisi, 2010). Mining entities operate without mining licences and Environmental Impact Assessments. ZELA (2011) has shown that many mining operations are taking place in Zvishavane district without mining licences and the Environmental Impact Assessment Certificates, to those few who possess mining certificates they are not meeting their commitments. Lack of transparency and accountability within government institutions has been observed as the major challenge deterring environmental protection efforts (Makaza, 2015). Monitoring mechanisms are ineffective due to rife corruption and bribes thereby perpetuating the violation of people's environmental rights.

\section{Conclusion}

This research aimed to examine the impact of artisanal small-scale mining activities on the environmental rights of people in the Mapanzure area in Zvishavane District. A qualitative research approach was employed to gather data for the research. Data were collected mainly through interviews and focus group discussions. The findings of the research highlights that the proliferation of small-scale gold and chrome mining due to the economic and political challenges facing the country have resulted in excessive land degradation, air pollution, water pollution and deforestation of forested land. Artisanal Small-scale mining continues to be the critical livelihood option for marginalised communities in rural Zvishavane and elsewhere in Zimbabwe. However, it has caused many environmental impacts which in turn endanger the rights, lives and livelihood pathways of rural communities. The research further underlines that there is weak implementation and poor governance of the mining laws in Zimbabwe. Responsible authorities such as the Environmental Management Agency and the Ministry of Mines and Mining have to ensure impartial application of the law to ensure sustainable mining and protection of the community's environmental rights. The weak implementation of the mining policies affects the marginalised communities who reside mostly in the rural areas of the country where most mining activities take place. Environmental degradation not only impacts the environment but has also crosscutting consequences which range from poor agricultural activities and poor health conditions.

\section{Implications}

This research has significant implications in that, if the environmental situation in Zvishavane district remains unchecked, the area is heading for untold ecological disasters including the destruction of the ecosystem and the 
loss of biodiversity due to unmonitored artisanal small-scale mining operations. The results of the study have valuable insights to policymakers and mining authorities in Zimbabwe so that artisanal small-scale miners' activities can be controlled through licensing, providing panners with permanent claims and operating permits because people mine illegally as the process of obtaining permits is difficult.

\section{Recommendations}

This paper recommends the enhancement of community participation so that indigenous communities can contribute to matters that affect their lives. The larger population of people in remote areas do not know the existing laws on environmental protection. The current legislation on mining must be reviewed and aligned to match international standards. Small-scale miners must reclaim their excavations to reduce land degradation and ecosystem disruptions. This will prevent people and livestock from falling into open shafts. The Environmental Management Agency must ensure that fines paid by offenders are channelled into projects intended to alleviate dangers of land degradation, air pollution and deforestation. Finally, transparency and accountability by law enforcers must be improved to ensure efficiency in the management and protection of the environment in Zvishavane district and Zimbabwe in general.

Land rehabilitation efforts and compensation mechanisms are equally important in the quest for protecting the environmental rights of vulnerable communities, in that case, small-scale miners should be compelled to ensure that they redress their environmental impacts. The Ministry of Small Scale and Medium Enterprises should improve the support given to small-scale miners in the form of financial assistance and equipment that can advance their activities especially with regards to technology and methods of mining. Most importantly, the government should expedite the process of recognising artisanal small-scale miners through legalizing their activities to avoid illegal and reckless mining. The implementation of appropriate institutional frameworks and legal policies will go a long way in holding small-scale miners accountable and responsible for their activities.

\section{Limitations and suggestions for further research}

The study has offered valuable insights into the challenges posed to the environmental rights of people in Mapanzure by conducting qualitative research. The results of the study would be transferable and generalised to other contexts if mixed methods were used. Due to the use of primarily qualitative methods, findings are trustworthy but cannot be entirely generalised to other contexts. The other weakness of the study relates to the use of the local language during the interviewing process with participants which required translation of the interview transcriptions to the English language. Though translations were thoroughly done by experts, some information might have been distorted. Although this study attempted to address the key environmental impacts of artisanal small-scale miners in Mapanzure there is still need for further research to understand why local communities perceive artisanal small-scale mining as the sole way to secure their livelihoods. The reasons why people resort to artisanal small-scale mining are complex and must be explored to gain a clear understanding of the livelihood challenges faced by marginalised communities in rural Zimbabwe.

\section{References}

Anderson, D. (2017). The Economics of Afforestation: A Case Study in Africa. World Bank: The Johns Hopkins University Press.

Arthur, F., Agyemang-Duah, W., Gyasi, RM., Yeboah, JY. \& Otieku, E. (2016). Nexus between artisanal and small-scale gold mining and livelihood in Prestea mining region. Geography Journal, 1-18.

Braun, V. and Clarke, V. (2006). Using thematic analysis in psychology. Qualitative Research in Psychology, $77-$ 101.

Brisman, A. (2014). Environmental and Human Rights. In: Bruinsma G., Weisburd D. (eds) Encyclopedia of Criminology and Criminal Justice. New York: Springer.

Chamber of Mines (2012). Report on Mining. Harare: Government Printers (Zimbabwe).

Chipika, J.T. \& Malaba, J.A. (2011). Indigenization and Economic Empowerment (IEE) in Zimbabwe: A Strategy for Wealth and Empowerment Creation for Poverty Reduction. Harare: Business Council of Zimbabwe (BCZ).

Fereday, J. \& Muir-Cochrane, E. (2006). Demonstrating rigor using thematic analysis: A hybrid approach of inductive and deductive coding and theme development. International Journal, 35.

Franks, D.M., (2017). Reconsidering the Role of Minerals and matter in International Development. In: Bryan, L. (Ed.), Mining for the Future. The Geological Society, 22-23.

Grant, D (2006). Independent qualified Person's Report, Blanket Mine in Zimbabwe, Caledonia Mining Corporation. Canada: Ontario.

Hammar, A., McGregor, J. \& Landau, L. (2010). Introduction: Displacing Zimbabwe: Crisis and construction in Southern Africa. Journal of Southern African Studies, 263-83.

Hawkins, T. (2009). The Mining Sector in Zimbabwe and its Potential Contribution to Recovery. Comprehensive Economic Recovery in Zimbabwe Working Paper Series. Harare: United Nations Development Programme. 
Hayes, K. (2008). Small-scale mining in Africa, A case for sustainable livelihood. Amsterdam: Common Fund for Commodities.

Hilson, G. (2016). Development minerals in Africa, the Caribbean, and the Pacific: Background study. In: Franks, D.M., Pakoun, L., Ngonze, C. (Eds.), Development Minerals in Africa, the Caribbean and the Pacific, ACPEU Development Minerals Programme. Brussels: United Nations Development Programme.

Hirons, M. (2014). Decentralizing natural resource governance in Ghana: Critical reflections on the artisanal and small-scale mining sector. Futures, 21-31.

International Institute for Environment and Development (2013). Responding to the challenge of artisanal and small-scale mining. How can knowledge networks help? London: International Institute for Environment and Development.

Kaseke, E. Chaminuka, L. and Musingafi, M. (2015). Mining and Minerals Revenue Distribution in Zimbabwe: Learning from Our Surroundings and Past Mistakes. Journal of Economics and Sustainable Development, 90-95.

Lincoln, Y. S., and Guba, E. G. (1985). Naturalistic Inquiry. Newbury Park, CA. Sage.

Mabhena, C. (2012). Mining with a 'Vuvuzela': Reconfiguring artisanal mining in Southern Zimbabwe and its implications to rural livelihoods. Journal of Contemporary African Studies, 219-33.

Makaza, D. (2015). When Extractives Come Home: An Action Research on the Impact of the Extractive sector on Women in Selected Mining Communities in Zimbabwe. International Journal of Sustainable Development, 45-72.

Mapuranga, R. (2020). Mining Zimbabwe. Harare: Timelison Media (Zimbabwe).

Mathe, M. and Phiri, A. (2016). The impact of mining on the Environment in Gwanda District Zimbabwe: A case study of Blanket Mine. Imperial Journal of Interdisciplinary Research, 503-512.

Mawowa, S. (2013). The political economy of artisanal and small-scale gold mining in central Zimbabwe. Journal of Southern African Studies, 921-936.

Mtisi, S. (2010). Chiadzwa Diamond Revenue Distribution: The Devil Lies in the Mining Contracts and the Tax Regime. Harare: ZELA.

Muremba, R. (2011). Overview of the Mining Taxation Regime in Zimbabwe, Zimbabwe Revenue Authority (ZIMRA). Harare: Southern Africa Resource Watch (SARW).

Murombo, T. (2013). Regulating mining in South Africa and Zimbabwe: Communities, the environment and perpetual exploitation. Law, Environment and Development Journal, 9-31.

Ndlovu, V., Ndhlovu, V., and Mpofu, M. (2019). “Against All Odds”. Female Small Scale Mine Owners in Gwanda, Zimbabwe. Journal of Sustainable Development, 1-9.

Ross, M.L (2001). Extractive Sector and the Poor. Washington DC: Oxfam America.

Rutherford, B. (2014). Organization and (de)mobilization of farmworkers in Zimbabwe: Reflections on trade unions, NGOs, and political parties. Journal of Agrarian Change, 214-39.

Rutherford, B. (2017). The land reform deception: Political opportunism in Zimbabwe's Land Seizure Era by Charles Laurie.

African Studies Review, 60(1), 212-214.

Scoones, I., Chaumba, B., M \& Wolmer, W. (2012). The new politics of Zimbabwe's lowveld: struggles over land at the margins. African Affairs, 527-50.

Spiegel, S. (2015). Shifting Formalization Policies and Recentralizing Power: The Case of Zimbabwe's Artisanal Gold Mining Sector. Society and Natural Resources, 543-558.

Telmer, K.H., \& Veiga, M.M. (2009). World Emission of Mercury from Artisanal and Small-Scale Gold Mining. Boston: Springer.

Thomas, A. (2000). The Environmental and Social Impacts of Mining in Wassa West District of Ghana. Geneva: Third World Network.

United Nations Conference on the Human Environment, (1972, 5 June). United Nations Environment Programme. Declaration of the United Nations Conference on the Human Environment, 1-4.

World Bank. (2013, November 21). Artisanal and Small-Scale Mining. Extractive Industries, 1-2.

Zimbabwe Environmental Law Association (ZELA) (2020). COVID-19: Mining Sector and Communities Situational Report. Harare: ZELA.

Zimbabwe Environmental Law Association (ZELA) (2011). Extractive Industries Policy and Legal Handbook: Analysis of the key issues in Zimbabwe's mining sector. Harare: ZELA.

ZELA and SARW (2011). Sowing Seeds of Advocacy Work on transparency and Accountability in the Extractive Sector in Zimbabwe. Harare: ZELA and SARW 